JOSING: Journal of Nursing and Health

Volume 2, Nomor 1, Desember 2021

e-ISSN: $2745-7877$

p-ISSN: 2746-0851

DOI: https://doi.org/10.31539/josing.v2i1.2964

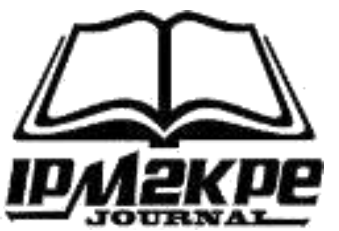

\title{
SINGLE PARENT PSYCHOLOGY WHO CONFIRMED POSITIVE COVID-19
}

\author{
Padila $^{1}$, Juli Andri ${ }^{2}$, Andry Sartika ${ }^{3}$, Muhammad Bagus Andrianto ${ }^{4}$, \\ Harsismanto, $\mathrm{J}^{5}$ \\ University of Muhammadiyah Bengkulu ${ }^{1,2,3,4}$ \\ Pematang Tiga Health Center \\ padila@umb.ac.id ${ }^{1}$
}

\begin{abstract}
This study aims to explore the psychological experiences of single parents with confirmed COVID-19. The design of this study is a phenomenological approach because what is being studied is experience. The participants involved were single parents with confirmed COVID-19, with the instrument used as an in-depth interview guide related to their psychological experiences with confirmed COVID-19. The results of this study obtained five themes, namely the transmission of covid-19 occurs due to infection from friends in the work environment and after traveling, feelings when confirmed with covid-19, single parents experience shortness of breath, anxiety, worry, fear, shaking, insomnia, headaches, and anxiety. Was. In self-care, single parents ask to be cared for independently at home by taking medicines, vitamins, herbs to maintain progress and experience changes in excessive eating patterns. This he also applies to his children so that children stay healthy. The conclusion is that single parents experience psychological problems, namely anxiety, with a moderate level when confirmed positive for COVID-19.
\end{abstract}

Keywords: Covid-19, Psychological, Single Parent, Phenomenology

\section{INTRODUCTION}

With the increasing number of Covid-19 spreads in Indonesia, the government has made several efforts to break the chain of the virus's reach. The Indonesian government has formed and activated a team for rapid action. Since January 18, 2020, Indonesia has conducted health checks at around 135 points at airports, on land, and at ports, using PCR test scanners and body temperature recording devices for everyone entering Indonesian territory by international health regulations. The Indonesian government has also implemented large-scale social restrictions to reduce transmission and morbidity from the disease. This disease also creates anxiety and anxiety for the entire global community.

Psychological disorders include anxiety, the characteristics of which are fear, concern for a certain period, constant worry, and nervousness in dealing with situations (Padila et al., 2021). Anxiety occurs a lot in single parents during the pandemic; many anxiety factors are felt them including fear of being home because of the reduction in employees, fear of being infected from the workplace; if he is optimistic for Covid-19, it will have an impact on the health of his family, especially children (Elbay et al., 2020). 
Single parents or single parents experience more anxiety in this issue. Based on the research results conducted by Wu et al., (2020), it was found that the highest level of single-parent anxiety, namely mild anxiety symptoms, contributed $20.7 \%$, moderate anxiety symptoms contributed $3.4 \%$, and signs of severe anxiety accounted for $0.5 \%$. These feelings arise in response to situations that are perceived as threatening. Tension often appears in individuals triggered by feelings of helplessness and hopelessness; when individuals experience this, it is customary to deal with the illness.

The research results conducted by Nurlaeli \& Nurwanti (2017) revealed an increase in the bond between mothers and children during the Covid-19 pandemic. This attachment is where the child is psychologically and emotionally very closely needing a mother figure. So if the single parent is positive, we can imagine how sad the child will be.

Although not everyone has the potential to have severe symptoms when infected with COVID-19, the rapid and complex spread of the virus makes single parents who are confirmed to be Covid-19 will experience many challenges and difficulties in accompanying their children because they have to isolate themselves, not at all. May come into contact in the process of caring for children. Imagine the psychological atmosphere experienced by single parents at that time. Not to mention, on the other hand, it is feared that the food consumption patterns of their children are not well maintained due to lack of attention from parents when they are sick, so there is a risk of changes in nutritional patterns that are less or excessive in the child (Larastati \& Munastiwi, 2021). It is also important to note that stimulating children's growth and development should not be stopped under any circumstances.

\section{RESEARCH METHOD}

The type of research that researchers use is qualitative research. Qualitative research generally explains and provides understanding and interpretation of different individual behaviors and experiences. Using a descriptive phenomenological approach, this method is expected to examine the psychological experiences of single parents who are confirmed positive for Covid-19.

This design was chosen because the researcher examines the breadth, richness, and depth of a person's experience. The sampling technique used is the accidental sampling method, which is a sampling technique found directly in the field and considered to be the characteristics of the sample.

The essential tool in this research is the researcher himself. Researchers will use data collection tools to assist research, namely by making researchers themselves as research tools equipped with a maintenance recorder that uses a voice recorder in the form of a cellphone.

\section{RESULTS}

Characteristics of Participants

Before conducting the research, the researcher will explain to single parents who are confirmed positive for Covid-19 about the research's objectives, benefits, and process, then provide a signed informed consent form to state their willingness to be a participant in the study. 


\section{Theme Analysis}

In qualitative research, data analysis is carried out during data collection and after data collection. When the researcher conducts the interview, the researcher must have completed a study of the respondent's answers. About data analysis, the model used is the Milles and Huberman model. Milles and Huberman's data analysis activities consist of: data reduction, data display, and conclusion drawing/verification, which are carried out interactively and continuously until complete so that the data reaches saturation. The Milles and Huberman method obtained five themes showing the psychological experiences of single parents who were confirmed positive for Covid-19 in single parents, namely:

Theme 1: Covid-19 transmission

Covid-19 transmission based on information from participants, namely:

"I was infected after a few days of visiting overseas, and my friends were also positive" (P1)

"infected after returning from overseas service" (P2)

"infected from work friends" (P3)

"infected in the office environment" (P4)

"Infected from work friends" (P5)

"infected by a friend from work who came home from overseas service" (P6)

"infected sometime after returning from a trip" (P7)

Theme 2: How do you feel when you find out that you are confirmed to have COVID19 based on information from participants, namely:

"Fear, sad and anxious" (P1)

"I feel panicked and worried" (P2)

"I feel anxious, and I don't sleep well" (P3)

"I feel very anxious" (P4)

"anxious and sad because I am afraid that my child will also be positive" (P5)

"I'm so worried, and I can't say anything" (P6)

"anxious, afraid, anxious and worried" (P7)

Theme 3: Sources of support for single parents

Sources of support obtained by single parents based on information from participants, namely:

"moral support from neighbors and every day we are given cooked food" (P1)

"Support from my family takes turns taking care of the children" (P2)

"support from colleagues sending money and necessities" (P3)

"From family and close neighbors take turns delivering food" (P4)

"from the environment and families take turns providing food" (P5)

"support from a sibling who took care of my child while I was isolation" (P6)

"from the closest people such as family, friends and the office" (P7)

Theme 4: What do single parents do in caring for themselves with COVID-19 based on information from participants, namely:

"I take medicines from the puskesmas and take vitamins regularly" (P1)

"Besides medicine, I eat a lot, so I can get healthy quickly and eat fruit" (P2)

"drink vitamins, sunbathe and also eat healthy food" (P3) 
"In addition to medicine, doctors also drink herbal ingredients such as boiled water sungkai" (P4)

"eat more vegetables, adhere to medication and sunbathe" (P5)

"activities are only at home, every time you leave the room you use a mask, take a warm shower" (P6)

"eat more, adhere to medication, sunbathe and use a mask when leaving the room" (P7)

Theme 5: How to care for children while the mother is in self-isolation based on information from participants, namely:

"I asked one of the families to look after my child" (P1)

"I ask Ms. who works at home to prepare the children's needs" (P2)

"Alhamdulillah, my neighbor is very kind and willing to accept my child when he is isolation" (P3)

"picked up by his father, stay at their house" (P4)

"My mother is at home, so she prepares all the needs" (P5)

"I asked my sister to come to Bengkulu to take care of the child" (P6)

"Stay at home, because I am also asymptomatic and my child is 13 years old too" (P7)

\section{DISCUSSION}

Coronavirus is a virus that attacks the respiratory system. The disease caused by this viral infection is called COVID-19. This virus can cause mild disorders of the respiratory system, severe lung infections, and even death. This virus can attack anyone, including pregnant women and breastfeeding mothers, such as the elderly, adults, children, and infants - unfavorable or direct contact with droplets. Early symptoms of coronavirus infection can resemble flu symptoms, namely fever, runny nose, dry cough, sore throat, and headache. After that, the symptoms may disappear and heal or even worsen. Patients with severe symptoms may experience high fever, cough with phlegm and even blood, shortness of breath, and chest pain.

The study results found that single parents experienced moderate anxiety levels, seen from their expressions, namely difficulty sleeping, shortness of breath, fear, worry, anxiety, erratic thoughts, and panic when they found out that they were confirmed positive for Covid-19. Based on the results of research conducted by Wu et al., (2020), it was found that the average mother experiences anxiety is ranging from moderate to mild levels. The stress experienced by single parents also impacts the family (Tirajoh et al., 2021).

Several studies have focused on single-parent mental health. Because COVID-19 is highly contagious, and there is still a lack of public awareness of its dangers, the essence of prevention is to reduce mass gatherings. In the policy of the central leadership, people undergo quarantine at home, single parents must work, and children study at home. Single parents and children are limited to limited space. In online consultations during the COVID-19 pandemic, single parents asked about many practical issues such as getting along with children when isolated and handling conflicts. Many single parents participate in relevant network lectures to improve communication with children, reduce single parent-child family conflicts and improve the quality of single parent-child relationships. In addition to the stress caused by the pandemic, the single parent-child relationship and the relationship between single 
parents also affect a single parent's mental health in difficult times, and a single parent's mental health can subsequently affect a child's psychological and physical health, creating a cycle of conflict. Therefore, single-parent mental health needs to be watched out for during the COVID-19 pandemic (Wu et al., 2020). Based on the results of research conducted by Febrianto (2021) with such conditions, it was found that the instability caused by the Covid-19 pandemic resulted in a substantial decrease in income. The ordeal faced by single parents is burdensome because they initially have to support their families during a weak economy.

Income vulnerability is a deep concern for single mothers. The Covid-19 pandemic has caused these mothers to empower themselves and develop various survival strategies. Mothers from middle-class families live frugally and are selective when buying what they need. Meanwhile, mothers from lower-class families carry out different survival mechanisms, ranging from careful spending, taking debt, and opening a business using their ex-husband's savings. In addition, they also work overtime, empower their children to help with work, diversify their work by opening a food stall to having an online shop.

Mothers, as single parents, play two roles to meet the socio-economic needs of the family. The mother's role as taking care of the household and child development is also the father's role as earning a living. These needs include physiological needs such as eating and drinking, security needs such as work and savings, the need for belonging and love, self-esteem needs, self-actualization needs, and neurotic needs (Batubara, 2018; Almeida et al., 2020).

Based on the results of the study, it was found that in taking care of himself who was confirmed to have COVID-19, single parents consumed drugs, vitamins, nutritious food, ate more often, took warm baths, sunbathed, used masks when leaving the room and still maintain a comfortable environment for children, by asking the family for help in maintaining and caring for him. The results of research conducted by Kurniati et al., (2021) the role of single parents reflected during the COVID-19 pandemic period was to maintain and ensure children live a clean and healthy life, accompany children in doing school work, carry out joint activities while at home, implement the environment. Comfortable for children, establish intense communication with children, play with children, become role models for children, provide supervision to family members, provide for and meet family needs, guide and motivate children, provide education, maintain religious values and make variations and innovation activities at home.

In addition, based on the results of research conducted by Dewi \& Khotimah (2020), during a pandemic, single parent parenting for children can be realized in the form of collaboration with families to maintain children's health, accompanying children to learn online, taking time to do activities together, creating a safe and comfortable environment, establishing intense communication with children, and carrying out variations and innovations in activities, at home.

Based on the study results, it was found that single parents received much support from the closest people, such as family-home and work environment. In line with the research results by (Padila et al., 2021), parents' experience in caring for sick children also received support from the family. Social support in the COVID-19 pandemic plays an influential role in overcoming the psychological pressure experienced by individuals during difficult times (Russell et al., 2020). Social support is positively correlated with self-efficacy, sleep quality, and mental health (Abayomi et al., 2020). While negatively associated with anxiety, stress, depression, and psychological pressure (Rumeysa et al., 
2020). Social support is significant in the psychological dimension to provide selfconfidence, improve coping mechanisms and quality of life (Padila et al., 2021; Santoso \& Listywan, 2020).

Social support in dealing with the current Covid-19 pandemic is significant in the psychological dimension. The positive effect of social support is confidence/selfconfidence, comfort, a sense of purpose in life, and security. Social support can reduce various forms of stress, improve coping mechanisms and improve quality of life.

\section{CONCLUSION}

The results of this study obtained five themes namely; the transmission of covid19 occurs due to returning to work and visiting crowded places, the feeling when you know that COVID-19 is confirmed, a single parent experiences a moderate level of anxiety; he gets support from family, the surrounding environment, and office friends. In caring for herself and her child, a single parent asks for help from her family, and in particular, she is obedient to taking medicine, eating a lot and being nutritious, sunbathing, consuming herbal drinks, and taking a warm bath.

\section{SUGGESTIONS}

The role of the family is expected to always accompany single parents in their anxious period, in addition to providing support, protection, and attention to their families with single parents. Mothers who are single parents in overcoming their anxiety must pray a lot, do remembrance and follow positive studies, and those who work outside the home further increase compliance with health protocols during the COVID19 pandemic to maintain family health.

\section{REFERENCES}

Almeida, M., Shrestha, A., \& Stojanac, D. (2020). The Impact of the COVID-19 Pandemic on Women's Mental Health. Arch Womens Ment Health, 23(1). https://doi. org/10. 1007/s00737-020-01092-2

Abayomi, O., Olaseni, O. S., Akinsola, S. F., \& Agberotimi, R. O. (2020) Psychological Distress Experiences of Nigerians During COVID-19 Pandemic; The Gender Difference, Social Sciences \& Humanities Open, 2(1). https://doi.org/10. 1016/j.ssaho.2020.100052

Batubara, I. K. (2018). Peran Orang Tua Tunggal dalam Memenuhi Kebutuhan Sosial Ekonomi Keluarga (Studi Kasus : Ibu sebagai Orang Tua Tunggal di Kelurahan Semula Jadi Kota Tanjungbalai). Repository Institusi Universitas Sumatera Utara. https://repositori.usu.ac.id/handle/123456789/7026

Dewi, P. A. S. C., \& Khotimah, H. (2020). Pola Asuh Single Parent pada Anak di Masa Pandemi Covid-19. Seminar Nasional Sistem Informasi (SENASIF), 4(1). https://jurnalfti.unmer.ac.id/index.php/senasif/article/download/324/279/

Elbay, R. Y., Kurtulmuş, A., \& Arpacioğlu, S. E. K. (2020). Depression, Anxiety, Stress Levels of Physicians and Associated Factors in COVID-19 Pandemics. Psychiatry Research, 290(2). https:// doi.org/10. 1016/j. psychres. 2020.113130

Febrianto, P. T. (2021). Strategi Bertahan Hidup Ibu Tunggal Mahasiswa Universitas Selama Pandemi COVID-19. Society, 9(1), 20-39. https://society.fisip. ubb.ac.id /index.php/society/article/view/301 
Kurniati, E., Alfaeni, D. K. N., \& Andriani, F. (2021). Analisis Peran Single Parent dalam Mendampingi Anak di Masa Pandemi Covid-19. Jurnal Obsesi: Jurnal Pendidikan Anak Usia Dini, 5(1), 241-256. https://obsesi.or. id/index.php/ obsesi/ article/view/541/pdf

Larastati, S. P., \& Munastiwi, E. (2021). Strategi Kreatif Orang Tua Single Parent dalam Membangun Sikap Empati Anak selama Masa Pandemi Covid-19. Potensia: Jurnal Kependidikan Islam, 7(1), 73-85. http://ejournal.uinsuska.ac.id/index.php/potensia/article/view/10557

Nurlaeli, D. R., \& Nurwanti, N. (2017). Kelekatan (Attachment) Ibu - Anak di Tengah COVID-19. Journal of Chemical Information and Modeling, 53(9). file:///C:/Users/User/Downloads/fvm939e.pdf

Padila, P., Andri, J., Sartika, A., Andrianto, M. B., \& Harsismanto, J. (2021). Pengalaman Single Parents dalam Merawat Anak yang Terkonfirmasi Positif Covid-19. Jurnal Kesmas Asclepius, 3(2), 41-48. https://doi.org/https://doi.org/10.31539/jka.v3i2.2896

Padila, P., Harsismanto, J., Andrianto, M. B., Sartika, A., \& Ningrum, D. S. (2021). Pengalaman Orangtua dalam Merawat Anak Retardasi Mental. Jurnal Keperawatan Asclepius, 3(1), 9-16. https://journal. ipm2kpe.or.id/ index.php/ JKA/article/view/2163

Russell, B. S., Hutchison, M., \& Tambling, R. (2020). Initial Challenges of Caregiving During COVID-19: Caregiver Burden, Mental Health, and the Parent-Child Relationship. Child Psychiatry Hum Dev 51,671-682. https://doi.org/ 10.1007/s10578-020-01037-x

Santoso, D. Y. A., \& Listywan, B. (2020). Efektifitas Hipnoterapi terhadap Efikasi Diri Remaja untuk Melakukan Diet Sehat. Jurnal Ilmiah STIKES Kendal, 10(2). https://doi.org/https://doi.org/10.32583/pskm.v10i2.732

Tirajoh, C. V, Munayang, H., \& Karupan, B. H. R. (2021). Dampak Pembelajaran Jarak Jauh terhadap Kecemasan Orang Tua Murid di Masa Pandemi Covid-19. Jurnal Biomedik: JBM, 13(1), 49-57. https://doi.org/10.35790/jbm.13.1.2021.31715

Wu, M., Xu, W., Yao, Y., Zhang, L., Guo, L., Fan, J., \& Chen, J. (2020). Mental Health status of Students' Parents during Covid-19 Pandemic and Its Influence Factors. General Psychiatry, 33(4). https://doi.org/10.1136/gpsych-2020-100250 